NBER WORKING PAPER SERIES

\title{
GLOBALIZATION AND GREENHOUSE GAS EMISSIONS: EVIDENCE FROM THE UNITED STATES
}

\author{
Claire Brunel \\ Arik Levinson \\ Working Paper 28372 \\ http://www.nber.org/papers/w28372 \\ NATIONAL BUREAU OF ECONOMIC RESEARCH \\ 1050 Massachusetts Avenue \\ Cambridge, MA 02138 \\ January 2021
}

This is a draft chapter for the forthcoming book, Handbook on Trade Policy and Climate Change, Edward Elgar Publishing, edited by Michael Jakob. The views expressed herein are those of the authors and do not necessarily reflect the views of the National Bureau of Economic Research.

At least one co-author has disclosed additional relationships of potential relevance for this research. Further information is available online at http://www.nber.org/papers/w28372.ack

NBER working papers are circulated for discussion and comment purposes. They have not been peer-reviewed or been subject to the review by the NBER Board of Directors that accompanies official NBER publications.

(C) 2021 by Claire Brunel and Arik Levinson. All rights reserved. Short sections of text, not to exceed two paragraphs, may be quoted without explicit permission provided that full credit, including $(\odot$ notice, is given to the source. 
Globalization and Greenhouse Gas Emissions: Evidence from the United States

Claire Brunel and Arik Levinson

NBER Working Paper No. 28372

January 2021

JEL No. F18,Q56

\section{ABSTRACT}

The US has been a global leader in regulating local air pollution and a global laggard in regulating greenhouse gases (GHGs). For decades, critics of US policy have expressed fears that stringent US regulations on local air pollution would lead to pollution havens overseas. Prior research, suggests that has not happened. But what about the converse fear? Are the less stringent US climate regulations causing the US to become a pollution haven for other countries' GHGintensive industries? We provide a decomposition of US manufacturing GHG emissions and find no evidence of offshoring either to or from the United States since 1990.

\section{Claire Brunel}

American University

School of International Service

4400 Massachusetts Avenue NW

Washington DC 20016-8071

brunel@american.edu

Arik Levinson

Department of Economics ICC 571

Georgetown University

3700 O St., NW

Washington, DC 20057

and NBER

Arik.Levinson@georgetown.edu 


\section{Introduction: Findings that surprised the authors}

How does globalization relate to US efforts to date—or lack of efforts—-to reduce greenhouse gas (GHG) pollution? Has the composition of US manufacturing shifted away from GHG-intensive industries, in the same way that it has for industries responsible for traditionally regulated local air pollution, such as sulfur dioxide $\left(\mathrm{SO}_{2}\right)$ and particulate matter $(\mathrm{PM})$ ? Has the US outsourced the manufacture of GHG-intensive goods, in the way that some observers worry about offshoring to less stringent countries, or pollution havens? Or alternatively, has the US, which has so far failed to regulate manufacturing GHG emissions at the national level, become a pollution haven for countries that have been trying to address climate change? If so, can we see that composition change or offshoring in changing patterns of international trade, or as it is popularized, “globalization”?

This paper begins to answer some of those questions, in part motivated by recent work by the two of us and others asking those same questions about globalization and local air pollutants. That work finds that while the real output of the US manufacturing sector has increased over the past four or five decades, the sector's output of local air pollutants such as $\mathrm{SO}_{2}$ and PM has declined. ${ }^{2}$ The bulk of that cleanup of US manufacturing can be explained by changes in the technology of production, rather than the composition of industries doing the production. Manufacturers pollute less per widget, rather than producing fewer polluting widgets and more clean gadgets. Of the remaining non-technological cleanup explained by the changing composition of US manufacturing - fewer widgets and more gadgets-little or none has been due to US industries being replaced by imports. In fact, as one of us has written, "even if the analysis is limited to imports from developing countries, U.S. imports shifted toward cleaner goods faster than U.S. domestic production” (Levinson, 2010).

All of those findings relate to local air pollutants rather than GHGs. We expected going into this project that we would merely replicate those answers for GHGs. The US manufacturing sector would be increasingly and substantially less GHG-intensive, with most of that cleanup explained by technological change not the composition of manufacturing, and with little or none

2 See Brunel (2017), Levinson (2009, 2010, 2015), and Walker and Shapiro (2018). 
of the remaining composition change due to trade, or globalization. What we find, however, differs in some important ways that surprised us, but in hindsight should have been expected.

Unlike local air pollutants emitted by US manufacturers, which have declined substantially since 1990, GHGs have declined by only 12 percent. That was our first surprise. Second, the US manufacturing sector has not shifted towards industries that are responsible for less GHGs. That, too, contrasts with the fact that the US manufacturing sector has shifted away from industries responsible for more local air pollution. That was our second surprise.

In hindsight, much of this makes sense. Local air pollutants have been regulated in the US since the 1970s, when the US levied some of the world's first and strictest standards on emissions of $\mathrm{SO}_{2}, \mathrm{PM}$, carbon monoxide (CO) and nitrogen oxides (NOx). Shapiro and Walker (2018) show that most of the local air pollution reductions were the consequence of those environmental regulations. By contrast, as of this writing, the US federal government has imposed no manufacturing-sector restrictions on GHGs. Some states such as California and Massachusetts have filled the gap starting in the late 2000s, but no national regulation has targeted manufacturing GHG emissions. So perhaps we should not have expected manufacturing GHGs to decline for the same reason that local air pollution declined, because local air pollution was regulated and GHGs were not.

Yet despite the lack of national efforts to regulate manufacturers' GHGs in the US, we might still have had reason to expect a pattern similar to that for local air pollution. Many of the same manufacturing sectors that emit local air pollutants—petroleum refining, cement, metalsalso emit GHGs. So regulations that target local air pollutants affect the same sets of industries. If the regulations on local air pollution shifted the composition of US manufacturing toward cleaner, less pollution-intensive sectors, that would also shift the US industrial composition toward less GHG-intensive sectors. In fact, that has not happened. While composition of US manufacturing has shifted towards goods that emit less local air pollution, the GHG composition has remained largely unchanged.

A second reason we might have expected US manufacturing GHGs to have followed a pattern similar to local air pollution involves the technology of abatement. Many of the GHGreducing technologies manufacturers use, or are expected to use, also happen to reduce local air pollution, mainly by reducing output or requiring more energy efficiency. For that reason, many 
US federal GHG regulations that have been proposed, but for various reasons have not taken force, describe reduced local air pollution as a “co-benefit” of reducing GHG emissions. ${ }^{3}$ A naïve expectation, based on that co-benefit relationship, is that regulations that have successfully reduced local air pollution from manufacturing since the 1990s will also have reduced GHG emissions from manufacturing.

It turns out, however, that those co-benefit relationships are asymmetric. Technologies used to abate GHG emissions_-reduced output and increased energy efficiency—also reduce local air pollution. But technologies used to abate local air pollution do not necessarily reduce GHGs. Over the past 50 years US manufacturers have switched to low-sulfur coal and installed end-of-smokestack technologies to trap particulates. Those reduce local air pollution with no effect on GHGs. They may actually increase GHGs if operating abatement technologies requires energy. Brunel and Johnson (2019) document this asymmetry, finding “no evidence that stringent local pollution regulation changes GHG emissions from the non-energy sectors.”

What does this mean for the questions we pose? Prior research showing that local air pollution declined substantially while manufacturing output increased does not necessarily imply that GHG emissions will have declined similarly. We find here that GHG emissions declined much less. And prior research attributing the reductions in local pollution from US manufacturing to the techniques used in production therefore have no implications for reductions in GHG pollution from US manufacturing.

Those findings are not entirely bad news. First, even though the US manufacturing sector has not shifted towards less GHG-intensive industries, manufacturing-sector GHG emissions have not kept pace with manufacturing output. Why not? Technology must explain the difference. For some reason manufacturers in specific industries emit fewer GHGs per dollar of output. Unlike with local pollution, no federal regulations targeting GHGs can be credited with that cleanup. Perhaps it has been due to efforts by US states, or market forces and energy prices.

${ }^{3}$ See, for example, the Regulatory Impact Analysis for the federal Clean Power Plan (EPA-452/R-15-003, August 2015), which projected climate benefits in 2025 of \$3.1 to \$35 billion, depending on the discount rates, and local air pollution benefits that averaged $\$ 12$ billion (in 2011 US\$). Also see Aldy et al., 2020. 
Either way, the technological cleanup is there, smaller than for local air pollution but moving in the right direction.

The second hopeful interpretation of these findings involves the composition of US manufacturing and GHG-intensive industries. As US trading partners gradually imposed regulations governing GHG emission, and the US federal government did not, we might fear the US turning into a pollution haven for countries taking climate change more seriously. In that case, we should expect to see US exports shifting towards even more GHG-intensive sectors and US imports shifting to cleaner ones. And, again, we find here that they did not. The composition of imports has not been shifting towards less GHG-intensive industries since 1990. That's true even if we focus on trade with high-income countries more likely to be regulating GHGs. US exports are equally GHG intensive as 30 years ago, and imports are, if anything, more GHGintensive. If there is any good news here, it is that the US is not becoming a pollution haven for industries relocating from countries that are trying to mitigate climate change. Any GHGs reduced by other countries do not, at least so far, seem to be leaking into US production.

\section{What we know so far}

Although this chapter is among the first to examine globalization and GHG emissions as it pertains to US manufacturing, the issues we raise are not new. That trade-environment debate is too extensive for review here, but we think four particular topics deserve mention: pollution havens, environmental Kuznets curves, environmental Engel curves, and decompositions of environmental changes into scale, composition, and technique.

\section{Pollution Havens}

The most directly relevant line of inquiry involves pollution havens. This is the concern that manufacturers facing strict environmental regulations will relocate their production facilities to countries with laxer policies - the pollution havens. Concerns about pollution havens, and 
fears of job losses in polluting domestic industries, have been a major obstruction to the passing of strict environmental regulations. ${ }^{4}$

For local pollutants, when any one country enacts a regulation, its environment becomes cleaner, either because its manufacturers incur the cost of cleanup (less pollution per widget) or because they relocate production abroad. Either option—cleanup or relocation-improves the local environment. But in the context of global pollutants like GHGs, the distinction between cleanup and relocation is critical. If national GHG reduction results from technology, the global climate improves. If national GHG reduction results from offshoring polluting industries, the regulating countries' efforts are wasted. This relocating to avoid GHG regulations is sometimes called "leakage." ${ }^{5}$ But leakage is merely a relabeling of concerns about pollution havens that date back to the 1970s.

The notion that manufacturers will relocate to pollution havens is anchored in theory, but empirical evidence for that relocation is mixed. ${ }^{6}$ Early work reviewed in Jaffe et. al (1995) did not find that environmental policies affected competitiveness, defined broadly. These early studies relied primarily on cross-sectional data, all that was available at the time. Using panel data, more recent work attempts to control for unobserved heterogeneity and policy endogeneity, finding some evidence of pollution havens. ${ }^{7}$ For example, Millimet and Roy (2016) show that US states with less stringent environmental policies have higher levels of inbound foreign investment. They are pollution havens. However, examining the EU Emission Trading Scheme, Branger et al (2013) do not find an increase in net imports of cement and steel. Yet other papers find small effects of trade on the environment (Cole and Eliott, 2003; Frankel and Rose, 2005). Overall, research has shown environmental policies to be only one of the many determinants of

${ }^{4}$ Dechezlepretre and Sato (2017); Semuels, Alana (2017), Do Regulations Really Kill Jobs? The Atlantic, https://www.theatlantic.com/business/archive/2017/01/regulationsjobs/513563/

${ }^{5}$ For a review of what we know about carbon leakage and how to address it, see Jakob (2020).

${ }^{6}$ For examples of theory, see Copeland and Taylor $(1994,1995)$. For mixed empirical evidence, see Dechezlepretre and Sato (2017).

${ }^{7}$ For a complete discussion of the challenges to measuring environmental stringency, see Brunel and Levinson (2016). For surveys of the more recent literature, see Brunnermeir and Levinson (2004), Dechezlepretre and Sato (2017), and Cherniwchan, Copeland and Taylor (2017). 
comparative advantage. Others—such as factor endowments and technology differencesremain much more important (Dechezlepretre and Sato, 2017; Cherniwchan et al, 2017).

In this chapter, we do not attempt to test for pollution havens in the context of GHG regulations, or whether the US in particular is a pollution haven for other countries' GHGintensive industries. We do not deploy a measure of GHG regulatory stringency, or try to identify why international trade patterns have changed. All we do is explore whether the patterns of US manufacturing production, imports, and exports over the past three decades are consistent with the US becoming a pollution haven for GHG-intensive industries relocating from countries enacting climate policies.

One of the reasons we cannot definitively attribute changes we see to pollution havens, or the lack of pollution havens, is that countries exhibit a pattern of changing pollution intensity as they grow. That empirical pattern—or one version of it anyway—has acquired the regrettable label "environmental Kuznets curve.”

\section{Environmental Kuznets curve}

In the 1992 World Development Report, and in Grossman and Krueger (1995), researchers noted a pattern that—sometimes—appeared when environmental degradation was plotted against regional incomes. Poor countries tended to be relatively unpolluted; middleincome countries the most polluted; and the richest countries relatively cleaner. The pattern looked like an inverted U. Because of its similarity to the unrelated relationship between income inequality and national incomes noted by Kuznets (1955), this pollution-income inverted-U pattern came to be called an "environmental Kuznets curve” (EKC).

That finding in the early 1990s was important because it documented for the first time that pollution and environmental degradation do not necessarily follow lock-step with economic growth. In fact, there are a number of reasons why in theory pollution in rich countries might decline. One explanation that we do not explicitly address here because we study only the manufacturing sector, is a compositional shift away from manufacturing towards less polluting service industries. As countries develop and transition from agriculture to industry, pollution increases. ${ }^{8}$ Later, as they develop further and transition from industry to services, pollution

\footnotetext{
${ }^{8}$ For evidence of this in Sub-Saharan Africa see Steckel et al (2020).
} 
declines. That historical pattern of development could explain the inverted-U-shaped patterns researchers observe. Importantly, however, it would have no predictive power for future correlations between economic growth and pollution. Who among us can say how polluting will be the next phase of development that replaces services?

A second explanation for the inverted-U-shaped pollution-income pattern, and one we do study here, is international trade. Countries may specialize in services or clean up the composition of their industries by importing from abroad the polluting industrial goods they still consume. That explanation gets at the core of the questions we ask at the top: have GHG emissions in the US been affected by changes in the composition and scale of goods it imports or exports?

One pattern that does emerge from the now voluminous set of papers studying EKCs is that pollutants with more geographically concentrated local damages (think of polluted streams) are cleaned up earlier and at lower levels of economic development. That pattern makes sense, because local pollution has less of a free-rider problem. Global pollutants like GHGs represent the worst-case free-rider problem. As a consequence, it is not surprising that very little of that voluminous EKC research finds inverted-U-patterns for GHG emissions, and those that do tend to be forecasting way outside of sample. ${ }^{9}$

For the most part, economics papers that estimate EKCs do not try to explain why those patterns occur. But in the very first paragraph of their 1995 paper, Grossman and Krueger propose a method for parsing those patters: "If the composition of output and the methods of production were immutable, then damage to the environment would be inextricably linked to the scale of ... economics activity.” Motivated by this insight, a different branch of research attempts to parse, or decompose, changes in pollution into changes in the scale, composition, and technique of economic activity. That decomposition is most closely related to the questions we pose here because a prime candidate for changes in the composition of economic activity is globalization. If rich countries are cleaner because they produce relatively fewer GHG-intensive goods (composition), and they produce fewer GHG-intensive goods because they import them

${ }^{9}$ See, for example, Narayan and Narayan (2010), Fosten et al (2012), or Holtz-Eakin and Selden (1995). 
from pollution havens (globalization), then that rich-country cleanup holds little hope for mitigating climate change.

Scale, Composition, Technique

Total pollution emitted by a country is simply the product total economic output and the sum of each industry's share of that output times its pollution intensity,

$$
P=\sum_{i} p_{i}=V \sum_{i} \frac{v_{i}}{V} \cdot \frac{p_{i}}{v_{i}}=V \sum_{i} \theta_{i} z_{i}
$$

where total pollution is $P$, pollution from each sector $i$ is $p_{i}$, total output is $V$, output of each sector is $v_{i}$, each sector's share of total output is $\theta_{i}$, and each sector's pollution intensity is $Z_{i}$. In the last term, $V$ is the scale, the $\theta$ 's are the composition, and the $z$ 's represent the technique. By holding the z's fixed in a given year (or “immutable”), and comparing how pollution actually changed in a country over time with how it would have changed based solely on $V$ and the changing $\theta$ 's , analysts decompose pollution changes documented in EKC papers into scale, composition, and technique described by Grossman and Krueger.

Switching equation (1) into vector form and totally differentiating it yields:

$$
d P=\boldsymbol{\theta}^{\prime} \mathbf{z} d V+V \boldsymbol{z}^{\prime} d \boldsymbol{\theta}+V \boldsymbol{\theta}^{\prime} d \mathbf{z}
$$

A change in emissions $(d P)$ in equation (2) has three channels. The first shows what would happen if total output changed and nothing else $(d V)$. That's the scale effect. More production should, everything else held equal, increase pollution. The second shows the effect of a change in the mix of goods produced $(d \theta)$, all else equal. That is the composition effect. A cleaner mix of industries will lead to lower emissions. And the third describes what happens if industries manage to reduce the pollution intensity of production $(d z)$, with no other changes. That last channel is the technique effect.

Prior work examines this decomposition for local air pollution in the US, Europe, and Canada. Levinson (2009, 2015) finds that between 1987 and 2001, the US manufacturing reduced pollution by 25 percent while real manufacturing output increased nearly the same amount. That cleanup cannot be explained by scale (which goes in the wrong direction, increasing) or the composition of industries. The overwhelming share of the cleanup, therefore, 
must be due to changes in the technique of production, the $z$ 's. Similar findings exist for the European Union (Brunel, 2017) and Canada (Cherniwchan and Najjar, 2020). And evidence points to the stringency of environmental regulation being an important factor behind this cleanup (Cherniwchan and Najjar, 2020; Shapiro and Walker, 2018).

All these papers find that composition plays only a small role and that trade has not been important to the cleanup of production. In fact, they find that imports are getting cleaner faster than domestic production, which suggests a shift of consumption towards cleaner goods.

That consumption shift raises a possibility not addressed by most of this decomposition research. There are two reasons a country's industrial composition might shift towards cleaner goods. First, its citizens might consume the same goods, but import the dirty ones. That's the presumption of the scale-composition-technique papers. But alternatively, a country's industrial composition could shift if its imports remain unchanged but the country's citizens consume a cleaner mix of goods. This might happen if polluting goods in aggregate have income elasticities less than one, or so-called “environmental Engel curves” are concave. Levinson and O’Brien (2018) investigate this explanation, and find that US households in more recent years do indeed consume a less polluting mix of goods. ${ }^{10}$ So some of the historic shift of US manufacturing sector away from polluting industries can be explained by American consumers’ choices, not globalization. If that is the case for GHGs, then that portion of the composition-related cleanup of manufacturing is unrelated to leakage or pollution havens, and represents good news for the climate.

Again, however, all the above work that decomposes emissions focuses on local pollutants that affect areas near emission sources, rather than global pollutants that affect the entire world regardless of location. And as noted, we might have expected different results for GHGs than for local pollutants. The United States was an early leader regulating local air pollutant but lags behind in regulating GHGs, with no national policy and only a few state-level rules. Since regulations have been found important to the local pollution cleanup, we should not expect the same cleanup for GHGs. While the GHG regulations imposed in other countries and proposed in the US are expected to reduce local air pollution, the reverse is not true. The local

${ }^{10}$ Allan et al (2015) show a similar result for New Zealand. 
pollution abatement efforts that began in the US back in the 1970 cannot be expected to have yielded GHG co-benefits.

\section{US Greenhouse Gas Emissions}

Because our goal is to document how globalization may have changed US GHG emissions, we need to start by documenting those. The bold line in Figure 1 plots the real value of US manufacturing output, deflated using 2011 industry-specific price indexes, and normalized to 100 in our base year, $1990 .{ }^{11}$ We combined the NBER-CES Manufacturing Industry Database, which stops in 2011, and the Census Bureau Annual Survey of Manufacturers (ASM), available on-line beginning in 2002. For the years from 2002 to 2011 when the two series overlap and differ slightly, we use a year-weighted average that puts more emphasis on the NBER-CES data in the earlier years and more weight on the ASM data closer to 2012. For the price deflation, the early PPIs come from the NBER-CES data, and later years from the Bureau of Labor Statistics (BLS). ${ }^{12}$ Manufacturing output grew slowly and unevenly, by about 27 percent.

The dashed lower line in Figure 1 plots actual GHG from manufacturing, approximated using all industrial emissions less mining and natural gas and petroleum systems from the Environmental Protection Agency (EPA) Greenhouse Gas Inventory Data. If the composition and production technologies remained the same, that dashed line plotting GHG output would mimic the solid line plotting manufacturing output. Instead, it drops, also slowly and unevenly. By 2016, GHGs from US manufacturing were about 12 percent below their 1990 levels. US manufacturing GHG emissions have fallen even though output grew, a difference that must be due to composition or technique.

To find the share of that cleanup due to composition, we predict US manufacturing emissions using equation (1). We multiply each industry's manufacturing output in each year $\left(v_{i t}\right)$ by its pollution intensity $\left(\mathrm{z}_{i}\right)$, where the pollution intensity is held fixed, or in Grossman and Krueger’s words, “immutable.” The industry-level detail necessary to calculate GHG pollution

${ }^{11}$ Except for computers, NAICS code 334, which we did not deflate.

${ }^{12}$ We provide more detail on the specific challenges of the deflation in the next subsection. 
intensities come from the EPA Greenhouse Gas Reporting Program (GHGRP), available for individual facilities from 2010 to 2016. Facilities that emit more than 25 thousand metric tons of carbon dioxide equivalent report emissions to the GHGRP. The data cover more than 8,000 facilities, 2,522 of which are in the manufacturing sector, and represent approximately $50 \%$ of total US GHG emissions. ${ }^{13}$ We aggregate the data to the industry level by summing total direct emissions across facilities within each six-digit manufacturing code. Dividing total emissions by total output creates an emissions coefficient for each six-digit industry. Each of the seven thin lines in Figure 1 predicts GHG emissions from US manufacturing using emissions intensities calculated using a different year of the industry-specific GHG data, from the 2010 through 2016 versions. Those thin lines demonstrate the effects of the scale and composition of US manufacturing on GHG emissions, holding constant GHGs per dollar of output.

Table 1 documents the changes in US manufacturing and GHG emissions depicted in Figure 1. From 1990 to 2016, US manufacturing grew 26.7 percent, GHG emissions fell 12.3 percent, and, if we predict manufacturing GHG emissions using equation (1) and the 2016 emissions intensities, those predicted emissions would have risen 26.2 percent.

The numbers in Table 1 and Figure 1 have a stark implication. The decline in GHG emissions from US manufacturing, though not large, has come from technology changes, not a decline in manufacturing output or the share of GHG-intensive industries. ${ }^{14}$ The seven thin lines in Figure 1 nearly overlay the thick line that plots manufacturing output, indicating that the relative share of GHG-intensive industries in US manufacturing has remained nearly constant. The reduction in GHG emissions from US manufacturing has not been due to the US switching to less GHG-intensive industries. That suggests, but does not entirely prove, that the US's lack of climate effort has not led to it becoming a pollution haven for global GHG-intensive industries. It could be, in theory, that global GHG-intensive industries have relocated to the US, and that US emissions would have declined even further in the absence of that leakage into the US. Ruling that out requires that we consider US imports and exports.

${ }^{13}$ GHGRP key facts and figures available at https://www.epa.gov/ghgreporting/key-factsand-figures.

${ }^{14}$ Note that declining GHGs from manufacturing have not been the result of manufacturers purchasing more power from utilities and generating less on-site. The share generated onsite has held steady at around 12 percent since 1998 (EIA, 2017). 
But before examining the international data, we need to secure two loose ends regarding Figure 1. The first involves the sources of data and levels of disaggregation. And the second involves a comparison with an analogous version of analysis of Figure 1 calculated for local air pollutants.

\section{Price deflation}

As noted, for the value of output (the vit's) we use the real, inflation-adjusted value of shipments. To adjust for inflation, we use industry-specific producer price indexes (PPIs) from two sources: the NBER-CES data and the Bureau of Labor Statistics (BLS). The two series are indexed at distinct points in time, and it makes a difference which one we choose. If we index prices in a year when a particular industry had abnormally high prices, then our analysis would presume that industry has a relatively larger share of overall manufacturing output and a lower share of emissions per unit of output. We would exaggerate that industry's size and understate its GHG-intensity. We present our main results here using prices fixed in 2011, the last year of overlap between the two series. For comparison, in Table 1 column (2), we also show results indexing prices fixed in 1998, the first year of overlap. Although the magnitudes change, our main conclusions do not.

The industry-specific price deflation matters particularly for energy-intensive industries that are key to GHG emissions. Oil prices peaked in 2009 and again in 2011-15, inflating the dollar value of shipments by energy-intensive industries. If we only deflate those industries' outputs by the overall PPI, that would exaggerate their real output during those years. Doing so would make it seem as though the US industry composition shifted towards GHG-intensive industries, when in fact only the prices of their products rose. Using industry-specific PPIs solves that problem.

For computer-related industries, industry-specific PPIs create a different problem. Many of those industries have seen spectacular drops in PPI. For example, the PPI for "Computer Storage Devices” (NAICS code 334112) fell by 90 percent from 1990 to 2016. Applying that price index directly would inflate the nominal output of computer storage by a factor of 10 , making it seem as though US manufacturing shifted dramatically to from that industry, when in fact only the quality-adjusted prices of its products fell. But we do not believe manufacturing a 
computer storage device that is 10 times better uses 10 times the GHG emissions. We have examined our results two ways, by dropping entirely from the analysis industries with the threedigit NAICS code 334 (Table 1 column (3)), and by including those industries but without adjusting their shipment values for price inflation (Table 1 column (1)). The difference is insignificant and we focus on the results that include the undeflated values for these computerrelated industries.

\section{Emission coefficients and the technique effect}

Because the EPA only recently began requiring facilities to report GHG emissions, the GHG emission coefficients can only be calculated for the later years of our sample (2010-2016). This means two things. First, we cannot estimate changes in pollution intensities over the whole time period and therefore technique will be calculated as a residual: the difference between actual emissions and emissions predicted from scale and composition. ${ }^{15}$

Second, because the emissions coefficients are available only at the end of our time period, the predicted residual technique effect is analogous to a Paasche price index of consumer price inflation. Recall that a Paasche index measures inflation by comparing this year's actual expenditures to what last year's expenditures would be at current prices. The alternative, a Laspeyres index, compares last year's actual expenditures to what this year's would be at last year's prices. If consumers react to price changes by purchasing more of the relatively less expensive goods, a Laspeyres index overstates inflation and a Paasche index understates it.

In our analyses, we are estimating the role of technology (the z's) on pollution from manufacturing, not the effect of price changes (the $p$ 's) on the cost of living. If over time the US manufacturing sector produces more output in industries with the fastest-falling pollution intensities, our Paasche index will overstate the technique effect. Without GHG intensity data from early years, we cannot make the comparison using the Laspeyres equivalent. But unlike with price inflation, no theoretical reasons would suggest that one index should be larger than another, and Levinson (2015) shows that the distinction is immaterial for local air pollutants.

15 That is the approach taken by almost all prior work on this topic for local air pollutants. The only exception that examines changes in pollution intensities, the z's, is Levinson (2015). 


\section{Aggregation}

The calculations behind Table 1 and Figure 1 require both aggregate and industry-level data. Our task would be simpler if the data on GHGs, production, prices, and international trade all used the same industry definitions, and did so consistently over time. They do not, and so we must improvise in a few places.

We start with the more than 400 manufacturing industries classified by six-digit NAICS codes from 1990 to 2016. And, in fact, we could have done all of the analysis in Figure 1 using those industry definitions. But in the next section, we use data on US imports and exports by industry, and so we need to change the level of disaggregation for two reasons.

First, the trade come from the UN Comtrade database, which are organized by Harmonized System (HS) product codes. We used concordances from Pierce and Schott (2012) to convert the Comtrade data from the HS classifications to six-digit NAIC industry codes. ${ }^{16}$

More difficult, with imports we need to account for GHG emissions embodied in intermediate goods not imported directly. Think of it this way. If a car is assembled in the US, using glass made in the US, steel imported from India, and rubber from Vietnam, then the US domestic GHG emissions come from assembly and glass production, not from steel or rubber production. All of the relevant GHGs are counted in the EPA emissions data, which include vehicle assembly and glass production, and appropriately exclude the steel and rubber. And all of the relevant industry production is included in the Census Bureau’s manufacturing output data. The data behind Figure 1 are complete.

If the US imports that same car from Korea, we want to know the amount of GHGs that would have been omitted in the US had the car been assembled here. We call those "US emissions displaced by imports." For that we need to know the emissions from all of the inputs to manufacturing that car, the inputs to those inputs, and so on ad infinitum up the supply chain. And, we also need to know what fraction of that car's intermediate inputs would typically have been imported, because importing the car itself wouldn’t displace those inputs' emissions.

${ }^{16}$ https://sompks4.github.io/sub_data.html 
To account for intermediate inputs to imports, we use the Bureau of Economic Analysis (BEA) matrices of total domestic requirements by industry for 2007 and 2012, also following NAICS codes. Using these input-output matrixes and the emissions and production data, we calculate 14 different pollution intensity coefficients for trade: 7 years of GHGRP emissions data and 2 years of BEA input-output matrices. The BEA input-output matrixes use a different set of industry codes. We create a concordance between the BEA industry codes and the NAICS codes, leaving us with 235 manufacturing industries. To be consistent across the analyses, domestic in Figure 1 and imports and exports in what follows, we collapse all of the analyses to these same 235 industries.

Using 235 BEA industries rather than 400-plus NAICS industries unavoidably understates any composition changes. For example, NAICS codes 331315 (aluminum sheet, plate, and foil manufacturing) and 331318 (other aluminum rolling, drawing, and extruding) are combined into a single BEA code. The BEA-level analysis of the composition effect will therefore miss any changes in the relative shares of those two NAICS industries. As a check, we created a version of Figure 1 (not reproduced here) using the NAICS-level disaggregation. The composition shift—predicted emissions based on 2016 GHG reporting-looks nearly identical. It still tracks the total manufacturing output closely. Using the more aggregate BEA industries does not affect our conclusion that nearly all the reduction in US manufacturing emissions has come from technique, not from a change in the composition of US manufacturing.

\section{US Industries and Local Air Pollution.}

We have one last important note to make about US GHG emission before moving on to globalization and trade. The pattern visible in Figure 1-manufacturing increasing but pollution decreasing, with the cleanup largely explained by technology rather than composition-is similar but less dramatic than that for local air pollutants documented by previous research for previous time periods. To compare our results here directly, rather than just by reference to prior papers, Figure 2 plots versions of Figure 1 calculated for local air pollution. The overall manufacturing pollution data and industry-level emissions used to calculate emission intensity coefficients both come from the National Emissions Inventory for four local pollutants- $\mathrm{NOx}, \mathrm{SO}_{2}$, $\mathrm{CO}$, and PM10. The four panels of Figure 2 largely corroborate prior findings. Manufacturing grew over 
the past few decades, as documented by the solid line, which is identical in each of the four panels. Pollution fell dramatically for three of the four local air pollutants, while the decrease in PM10 emissions is more similar to the GHG trends. And while there may have been a small composition shift towards cleaner industries, most of the gap between the growth in manufacturing and the decline in pollution must be explained by technique. The pattern is more pronounced for local air pollutants in Figure 2 than for GHGs in Figure 1. As before, Table 1 reports the specific percentage changes.

The difference between these calculations for global and local pollutants is unsurprising given the regulatory landscape in the US. Local pollutants are subject to the Clean Air Act (CAA), which since the 1970s has required that every county in the US meet uniform national air quality standards. Counties that fail to achieve the standards must impose policies to reduce emissions. The national standards are tightened intermittently, and research has shown them to have resulted in less local air pollution. ${ }^{17}$ GHGs, on the other hand, remain largely unregulated in the US, at least at the national level. No federal regulation governs GHGs emissions from manufacturing. Two regions did implement their own GHG policies in the late-2000s—-the Northeast's Regional Greenhouse Gas Initiative and California's Global Warming Solutions Act—but only the Californian plan covers the industrial sector. The contrast in US regulatory stringency between local and global pollutants may explain why the decline in GHG pollution from manufacturing has been smaller than the decline in most local air pollutants.

Figure 1 shows that GHG emissions from US manufacturing have declined while US manufacturing output increased. That does not rule out the possibility of the US acting as a pollution haven for countries that have regulated GHGs more aggressively. It could be that US manufacturing emissions would have fallen more without that leakage. To examine that possibility, we turn to the international trade data.

\section{Finally, Globalization}

In principle, we use the same strategy to study emissions due to US imports and exports as we do for US domestic GHG emissions. We compare changes in the dollar value of shipments

\footnotetext{
${ }^{17}$ For recent evidence, see Shapiro and Walker (2018), Cherniwchan and Najjar (2020) and Chan and Zhou (2020).
} 
to changes in the GHG emissions predicted by those shipments, where the predictions come from changes to their scale and composition, holding technology_-GHGs per dollar of valueconstant for each industry. We calculate versions of equation (1) applied to trade:

$$
P^{T F}=\sum_{i} p_{i}^{T F}=V^{T F} \sum_{i} \theta_{i}^{T F} z_{i}
$$

where TF refer to "trade flows," either imports (M) or exports (X). ${ }^{18}$

For exports, the emissions coefficients $\left(z_{i}\right)$ are the same as used for the US domestic analysis. They are based on US data and describe technology employed in US manufacturing. Pollution from exports, $P^{X}$, then represents the amount of pollution emitted in the US from manufacturing those exports.

For imports, we need to make an additional adjustment to the emissions coefficients. We want pollution, $P^{M}$, to represent pollution that would have been emitted in the US if the imported goods had been produced at home. This is the relevant metric to study pollution offshoring since it tells us how much US pollution has been relocated abroad. But the trade data only contain information on the value of the good that crossed the border, not the inputs into its production. The imported car used steel, rubber, and glass, and manufacturing those intermediate inputs also created GHGs. Failure to account for intermediate inputs would understate the pollution content of imported final products, and understate the US emissions displaced by those imports.

To estimate the value of intermediate inputs into imported goods, we use the Leontief (1970) input-output method to create pollution indices that capture the entire production chain. Briefly, total produced output can be described by vector $\boldsymbol{x}$ of the output of each of $n$ industries. Some of that produced output is final product, and some becomes intermediate inputs to other industries. The vector $\boldsymbol{x}$ can be divided into those two components:

$$
x=C x+y
$$

where $\boldsymbol{y}$ is a vector of $n$ final product output values going to consumers, one from each of $n$ industries, and $\boldsymbol{C}$ is an $n \times n$ “direct requirements” matrix. Each element $c_{i j}$ represents the dollar value of input industry $i$ needed to produce one dollar's worth of output industry $j$. While the US

${ }^{18}$ See Kander et al (2015) for a related approach known as "greenhouse gas accounting.” 
production data report total output $\boldsymbol{x}$, which we need to estimate total GHG emissions, the import data only report $\boldsymbol{y}$, omitting the value of intermediate inputs. We estimate what $\boldsymbol{x}$ would be for imports by solving for $\boldsymbol{x}$ in equation (4):

$$
x=[I-C]^{-1} y=T y
$$

The matrix $\boldsymbol{T}=[\boldsymbol{I}-\boldsymbol{C}]^{-1}$ is the Leontief "total requirements" matrix. Each element $t_{i j}$ contains the dollar value of input $i$ used to produce output $j$, including all the inputs $i$ used by other industries that are themselves inputs to $j$. The vector $\boldsymbol{x}$ in equation (5) thus tells us the total amount of all manufactured goods used to produce trade flow $y$. We can therefore generate GHG emission coefficients for our trade flows by multiplying the total requirements matrix by our US, domestic, final-product emission intensities:

$$
\mathbf{z}^{*}=\mathbf{z}^{\prime}[\mathbf{I}-\boldsymbol{C}]^{-1}
$$

As a final step, it is necessary to correct the total requirements matrix to account for the fact that inputs into production are not necessarily produced domestically. They could themselves be imported. A car imported to the US from Korea might use steel as an input, but if that car had been assembled in the US the steel might also have been imported. In that case importing the car displaces US emissions from car manufacturing, but does not displace US emissions from steel manufacturing. Without this adjustment, the emissions coefficients calculated in equation (6) data would overstate the pollution embodied in imports. Technically, this is done by constructing a vector $(\boldsymbol{d})$ of the share of each industry supplied by domestic production:

$$
\mathbf{z}^{* *}=\mathbf{z}^{\prime}[\boldsymbol{I}-\operatorname{diag}(\boldsymbol{d}) \boldsymbol{C}]^{-1}
$$

where $[\boldsymbol{I}-\operatorname{diag}(\boldsymbol{d}) \boldsymbol{C}]^{-1}$ is the total domestic requirement matrix.

The BEA input-output data contain versions of this matrix, $[\boldsymbol{I}-\operatorname{diag}(\boldsymbol{d}) \boldsymbol{C}]^{-1}$. We multiply that by our US emissions coefficients $\mathbf{z}$ to generate the total emissions coefficients $\mathbf{z}^{* *}$. Each element of the vector $\mathbf{z}^{* *}$ thus contains the total GHG emissions necessary to produce one dollar's worth of final product, including all of the GHGs emitted by inputs to that final product, inputs to those inputs, and so on. There are two years of BEA data, 2007 and 2012, and seven years of pollution indexes from the GHGRP, 2010-2016. That gives us 14 different possible $\mathbf{z}^{* *}$ vectors. Using those $z^{* *}$ coefficients in place of the $z$ 's in equation (3) yields predictions $P^{M}$ of 
the total GHG emissions embodied in imports, including upstream emissions from inputs, and where the predictions are based on the scale and composition of those imports.

\section{Greenhouse Gas Emissions and US Imports and Exports}

Figure 3 begins to investigate the potential role of international trade in US GHG emissions changes. The first line plots the predicted GHG emissions from US domestic manufacturing, using the 2010-through-2016 GHGRP values. Though it's hard to see in the figure, the bottom line is actually a set of lines: seven thin lines each depicting emissions predicted by one of the seven GHGRP years, and one thicker line using the average. They replicate the predicted emissions lines in Figure 1, and plot how US GHG emissions would have changed based solely on the scale and composition of US manufacturing production.

The middle lines in Figure 3 plot predicted US GHG emissions from US exports, using equation (3) and the emissions coefficients from equation (7). Again, though it may be hard to see in the figure, there are multiple lines along this middle tier: 14 thin lines depicting export emissions, one for each year of the BEA input-output matrixes and 7 years of GHGRP data, and one thick line depicting the average. Emissions embodied in exports nearly doubled. ${ }^{19}$

On the surface, the middle lines in Figure 3 make it seem as though the US has been a pollution haven. It is increasingly exporting GHG-intensive goods. But leaping to that conclusion would be wrong for two reasons. First, and most obviously, note that the top lines plot predicted GHG emissions from US imports, which nearly quadrupled since 1990. If the US were acting as a pollution haven for more stringent countries, the US should be importing the clean goods. Instead, it is increasingly importing GHG-intensive goods, at a faster rate than it is exporting GHG-intensive goods.

Second, both trade lines in Figure 3 include both the scale and composition. We cannot tell looking at Figure 3 alone whether predicted pollution embodied in exports doubled because the volume of exports doubled, because the type of exports shifted towards more GHG-intensive industries, or both.

19 The surge in exports in 2007 is driven by a single industry: Other aircraft parts and auxiliary equipment manufacturing. Since this industry is the second most polluting in our dataset, this increase has a large effect on our predicted emissions. Removing this industry, predicted emissions for exports in 2007 are quite close to predicted emissions from manufacturing. 
To separate scale from composition, the top left panel of Figure 4 plots the dollar value of US exports alongside the predicted GHG emissions from exports, both indexed so that $1990=100$. The dollar value represents scale, which has more than doubled over time, ${ }^{20}$ and the predictions combine scale and composition. Both hold technique fixed. With considerable variation over time, GHGs embodied in exports grew approximately as fast as the dollar value of exports. If anything, by the end of the time period, predicted embodied GHGs had grown less quickly than the value of exports. If the GHG-intensive industries had been relocated to the US because of its lack of climate policy, the GHGs predicted in exports should be growing faster than the value of exports.

One possibility is that concerns about leakage of GHG emissions to the US only apply to industries relocating from other high-income countries that have implemented strict carbon policy. To examine, that, the top middle panel of Figure 4 plots the same figure for US exports to high-income countries, using the World Bank’s classifications. The figure displays no evidence for that concern. Predicted pollution embodied in US exports to other high-income countries track fairly closely the dollar value of US exports. For exports to high-income countries, there has been remarkably little change in the composition of US industries with respect to their GHG intensity.

A similar picture emerges on the import side. The top right panel of Figure 4 plots the real dollar value of US imports alongside the predicted GHG emissions from imports. They also track extremely closely. Over time, the US has not been importing more relatively GHGintensive goods. Imports have risen 229\% (Table 1) — the scale effect-and the combined scale and composition effect has risen by about the same amount. The right-hand panel of Figure 6 plots those same two lines for high-income countries, with the same result. If anything, by the end of the period US imports from high-income countries had shifted slightly towards more pollution-intensive goods, not less. That is the opposite of what would be happening if the US were attracting polluting industries relocating from stringent countries. ${ }^{21}$

${ }^{20}$ US exports increased $126 \%$ between 1990 and 2016 (Table 1).

${ }^{21}$ To be sure, not all high-income countries have more stringent regulation than the US. However, separating out the three regions that implemented GHG emissions trading schemes over our period - the European Union, Australia, and Canada - yields the same conclusion: the US has not become a pollution haven for more regulated countries. 
While national US climate policy has lagged, California and some northeastern states did implement GHG regulations starting in 2009. One could therefore wonder if after 2009 some leakage occurred from the United States to less regulated countries. If so, we should see in our data the composition of imports shifting to more pollution-intensive industries, and the composition of exports to less pollution-intensive industries. The bottom center and right panels of Figure 4 show pollution embodied in trade with low-income countries. Exports do show some compositional shift towards clean industries. ${ }^{22}$ However, US imports from low-income countries shifted towards cleaner goods faster than exports to the same group, faster than imports from other groups, and faster than US domestic production. There is therefore no evidence of offshoring of GHG pollution from the United States to low-income countries.

Recall that these calculations of predicted pollution content are based on US pollutionintensity. As such, they do not measure the actual pollution embodied in imports. That depends on foreign technologies of production and abatement, about which we have no data. Instead, these figures depict the amount of pollution that would have been emitted in the US if imports had been produced domestically - the amount of US pollution displaced by imports. Overall, the pollution embodied in imports has increased significantly, which appears to be primarily driven by a rise in the value of imports rather than a shift in the composition of imports.

The composition of US manufacturing, imports, and exports has not shifted in a way that would suggest the lack of national US climate policy has altered trade patterns.

\section{Conclusion: Bad News or Good?}

We see two big-picture trends here. First, the US manufacturing sector is responsible for shrinking GHG emissions, a cleanup that is not explained by the scale of output, which has been growing, or the mix of industries, which has not significantly shifted in GHG-intensity. It must be that US manufacturing has been using less GHG-intensive technologies. That represents good news, although the cleanup so far has been small.

${ }^{22}$ During the 2008 financial crisis, US exports to low-income countries plummeted, which explains the sudden decrease in predicted emissions. One export category - apparel manufacturing - weathered the crisis and drove the increase in exports (black line) over that period, but since it is not a highly GHG-intensive industry we do not see the same increase in predicted embodied emissions. 
Second, the composition of US manufactured exports has not shifted towards GHGintensive industries, nor has the composition of US imports shifted towards clean industries. Both would be expected if the US's lack of national climate policy were causing it to become a pollution haven for countries enacting climate policies. That doesn't necessarily represent good news. It could be that other countries' climate polices do not affect trade patterns because they are not terribly effective. Or, it could be that other countries do have strict climate policies, and those are not undermined by leakage of GHG emitting industries to countries with lax climate policies.

If other countries have imposed stricter GHG limits, why would GHGs not leak from strict countries to the US? Here we can only speculate. Perhaps they do leak, but there are more attractive pollution havens than the US. It could be that the GHG-intensive industries are the least geographically mobile. Relocating them to take advantage of relative differences in climate policy might be difficult. Ederington, et al (2005) provide some evidence for this in the context of all pollution, not necessarily GHG emissions. It could be that industries with high GHG emissions also emit other air pollutants that are regulated strictly in the US. In that case industries relocating to avoid strict GHG regulations would not want to come to a country with strict local air pollution regulations.

In the end, the results here represent less a case of good news than a lack of bad news. The US has not been importing increasing shares of GHG-intensive goods from high-income countries. That would have been bad news, because it would have meant that not only had the US federal government failed to address climate change, but that its failure to do so had been undermining other countries efforts to address climate change. Thankfully, that does not appear to be happening. At the same time, for some reason, the US has slowly been reducing GHG emissions from the manufacturing sector, almost exclusively due to changes in emissions per unit of output within industries, rather than a shift in the types of industries that comprise US manufacturing.

\section{References}

Aldy, Joseph, Matthew Kotchen, Mary Evans, Meredith Fowlie, Arik Levinson, Karen Palmer. 2020. “Deep flaws in a mercury regulatory analysis” Science 368(6488):247-248. 
Allan, Corey, Suzi Kerr, and Campbell Will. 2015. “Are we turning a brighter shade of green? The relationship between household characteristics and greenhouse gas emissions from consumption in New Zealand. Motu Working Paper 15-06, Motu Economic and Public Policy Research.

Branger, Frédéric, Philippe Quirion, Julien Chevallier, 2017. “Carbon Leakage and Competitiveness of Cement and Steel Industries Under the EU ETS: Much Ado About Nothing” The Energy Journal 37(3):109-135.

Brunel, Claire and Erik Johnson. 2019. “Two Birds, One Stone? Local Pollution Regulation and Greenhouse Gas Emissions” Energy Economics 78:1-12.

Brunel, Claire and Arik Levinson. 2016. "Measuring the Stringency of Environmental Regulation" Review of Environmental Economics and Policy 10(1):47-67.

Brunel, Claire. 2017. "Pollution Offshoring and Emission Reductions in European and US Manufacturing” Environmental and Resource Economics 68(3):621-641.

Brunnermeier, Smita and Arik Levinson. 2004. "Examining the Evidence on Environmental Regulations and Industry Location" Journal of the Environment and Development 13(1):6-41.

Chan, Ron and Yichen Christy Zhou. 2020. "Regulatory Spillover and Climate Co-benefits: Evidence from the New Source Review Lawsuits" SSRN Working Paper: http://dx.doi.org/10.2139/ssrn.3399713.

Cherniwchan, Jevan, Brian R. Copeland, and M. Scott Taylor. 2017. "Trade and the Environment: New Methods, Measurements, and Results” Annual Review of Economics 9:59-85.

Cherniwchan, Jevan and Nouri Najjar. 2020. "Environmental Regulations and the Clean-Up of Manufacturing: Plant-Level Evidence” Review of Economics and Statistics, forthcoming.

Cole, Matthew. 2004. "U.S. environmental load displacement: examining consumption, regulations and the role of NAFTA" Ecological Economics 48(4):439-450.

Cole, Mathhew, Robert Elliott, and Liyun Ahang. 2017. "Foreign Direct Investment and the Environment” Annual Review of Environment and Resources 42:465-87.

Dasgupta, Susmita, Benoit Laplante, Hua Wang, and David Wheeler. 2002. "Confronting the Environmental Kuznets Curve" Journal of Economic Perspectives 16(1):147-168.

Dechezleprêtre, Antoine and Misato Sato. 2017. "The Impacts of Environmental Regulations on Competitiveness" Review of Environmental Economics and Policy 11(2):183-206.

Ederington, Josh, Arik Levinson, and Jenny Minier. 2005. "Footloose and Pollution-Free" Review of Economics and Statistics 87(1):92-99.

Fosten, Jack, Bruce Morley, and Tim Taylor. 2012. “Dynamic misspecification in the environmental Kuznets curve: Evidence from CO2 and SO2 emissions in the United Kingdom” Ecological Economics 76:25-33. 
Frankel, Jeffrey and Andrew Rose. 2005. "Is Trade Good or Bad for the Environment? Sourting Out the Causality" Review of Economics and Statistics 87(1):85-91.

Grossman, Gene and Alan Krueger. 1995. “Economic growth and the environment” Quarterly Journal of Economics 110(2):353-77.

Hettige, Hemamala, Muthukumara Mani, and David Wheeler. 2000. "Industrial Pollution in Economic Development: The Environmental Kuznets Curve Revisited” Journal of Development Economics 62(2):445-476.

Hilton, F.G. Hank and Arik Levinson. 1998. "Factoring the Environmental Kuznets Curve: Evidence from Automotive Lead Emissions" Journal of Environmental Economics and Management 35(2):126-141.

Holtz-Eakin, Douglas, and Thomas Selden. 1995. "Stoking the fires? CO2 emissions and economic growth” Journal of Public Economics 57(1):85-101.

Jaffe Adam, Steven Peterson, Paul Portney, and Robert Stavins. 1995. "Environmental Regulation and the Competitiveness of U.S. Manufacturing: What Does the Evidence Tell Us?” Journal of Economic Literature 33(1):132-163.

Jakob, Michael. 2020. “Carbon Policy and International Trade” Mimeo

Kander, Astrid, Magnus Jiborn, Daniel D. Moran, Thomas O. Wiedmann. 2015. "National greenhouse-gas accounting for effective climate policy on international trade” Nature Climate Change 5:431-435

Klein, Roger and Francis Vella. 2010. "Estimating a class of triangular simultaneous equations models without exclusion restrictions” Journal of Econometrics 154:154-164.

Kuznets, Simon. 1955. "Economic growth and income inequality" American Economic Review 45:1-28.

Leontief, Wassily. 1970. "Environmental repercussions and the economic structure: An inputoutput approach” Review of Economics and Statistics 52(3):262-71.

Levinson, Arik. 2009. "Technology, International Trade, and Pollution from U.S. Manufacturing" American Economic Review 99(5):2177-2192.

Levinson, Arik. 2010. "Offshoring pollution: Is the U.S. increasingly importing polluting goods?" Review of Environmental Economics and Policy 4(1):63-83.

Levinson, Arik. 2015. "A Direct Estimate of the Technique Effect: Changes in the Pollution Intensity of US Manufacturing 1990-2008" Journal of the Association of Environmental and Resource Economists 2(1):43-56.

Levinson, Arik and James O’Brien. 2019. "Environmental Engel Curves: Indirect Emissions of Common Air Pollutants" Review of Economics and Statistics 101(1):121-133.

Millimet, Daniel L. and Jayjit Roy. 2016. "Empirical tests of the pollution haven hypothesis when environmental regulation is endogenous” Journal of Applied Econometrics 31:652677. 
Narayan, Paresh Kumar and Seema Narayan. 2010. "Carbon dioxide emissions and economic growth: Panel data evidence from developing countries” Energy Policy 38(1):661-666.

Panayotou, Theodore. 1997. "Demystifying the Environmental Kuznets Curve: Turning a Black Box into a Policy Tool” Environment and Development Economics 2(4):465-84.

Shapiro, Joseph and Reed Walker. 2018. "Why Is Pollution from US Manufacturing Declining? The Roles of Environmental Regulation, Productivity, and Trade” American Economic Review 108(12):3814-54.

Steckerl, Jan Christoph, Jerome Hilaire, Michael Jakob, and Ottmar Edenhofer. 2020. "Coal and carbonization in Sub-Saharan Africa" Nature Climate Change 10:83-88

US Energy Information Administration (EIA) 2017, "Energy Use and Energy Intensity of US Manufacturing-Data from the 2014 Manufacturing Energy Consumption Survey (MECS)” www.eia.gov/consumption/manufacturing/reports/2014/enduse_intensity.

World Bank. 1992. World Development Report 1992. New York: Oxford University Press. 
Table 1. Percentage Changes 1990-2016

\begin{tabular}{|c|c|c|c|}
\hline & Base Case & Alternate & Second Alternate \\
\hline & (1) & (2) & (3) \\
\hline \multicolumn{4}{|l|}{ Total value } \\
\hline US Manufacturing & 26.7 & 1.8 & 27.2 \\
\hline Imports & 229.0 & 174.6 & 211.2 \\
\hline $\begin{array}{l}\text { From low-income } \\
\text { countries }\end{array}$ & 857.9 & 1155.0 & 864.8 \\
\hline Exports & 126.0 & 88.7 & 129.9 \\
\hline \multicolumn{4}{|l|}{ US Pollution Emissions } \\
\hline GHGs & -12.3 & -12.3 & $-12.3 *$ \\
\hline PM10 & -12.1 & -12.1 & $-12.1 *$ \\
\hline $\mathrm{SO}_{2}$ & -83.2 & -83.2 & $-83.2 *$ \\
\hline $\mathrm{CO}$ & -37.9 & -37.9 & $-37.9 *$ \\
\hline NOx & -42.6 & -42.6 & $-42.6 *$ \\
\hline \multicolumn{4}{|l|}{$\begin{array}{l}\text { Pollution predicted by } \\
\text { scale and composition }\end{array}$} \\
\hline US GHGs & 26.2 & 16.4 & 25.9 \\
\hline Imported GHGs & 253.8 & 200.2 & 248.3 \\
\hline $\begin{array}{l}\text { From low-income } \\
\text { countries }\end{array}$ & 377.9 & 520.8 & 379.5 \\
\hline Export GHGs & 79.2 & 48.6 & 86.4 \\
\hline $\begin{array}{l}\text { Share of cleanup from } \\
\text { composition }^{\mathrm{a}}\end{array}$ & 1.3 & -100.3 & 3.4 \\
\hline
\end{tabular}

Notes: Reported numbers are changes relative to $1990=100$. The base case in column (1) adjusts for inflation using 2011 industry prices, and includes NAICS 334 (computers) without deflating. The alternate case in column (2) adjusts for inflation using 1998 industry prices, and includes NAICS 334 without deflating. Column (3) adjusts for inflation using 2011 industry prices, and removes NAICS 334. All predicted pollution calculations are based on 2016 GHGRP reporting. For imports and exports, predicted pollution is an average of the results using the two input-output matrices. * Total manufacturing emission numbers back to 1990 do not provide an industry breakdown specific enough to remove only NAICS 334 (computers). These figures are therefore the decrease in total manufacturing emissions, including NAISC 334.

a Share calculated as (total value - pollution predicted by scale and composition) / (total value - US pollution emissions) 
Figure 1. Real manufacturing output and GHG emissions

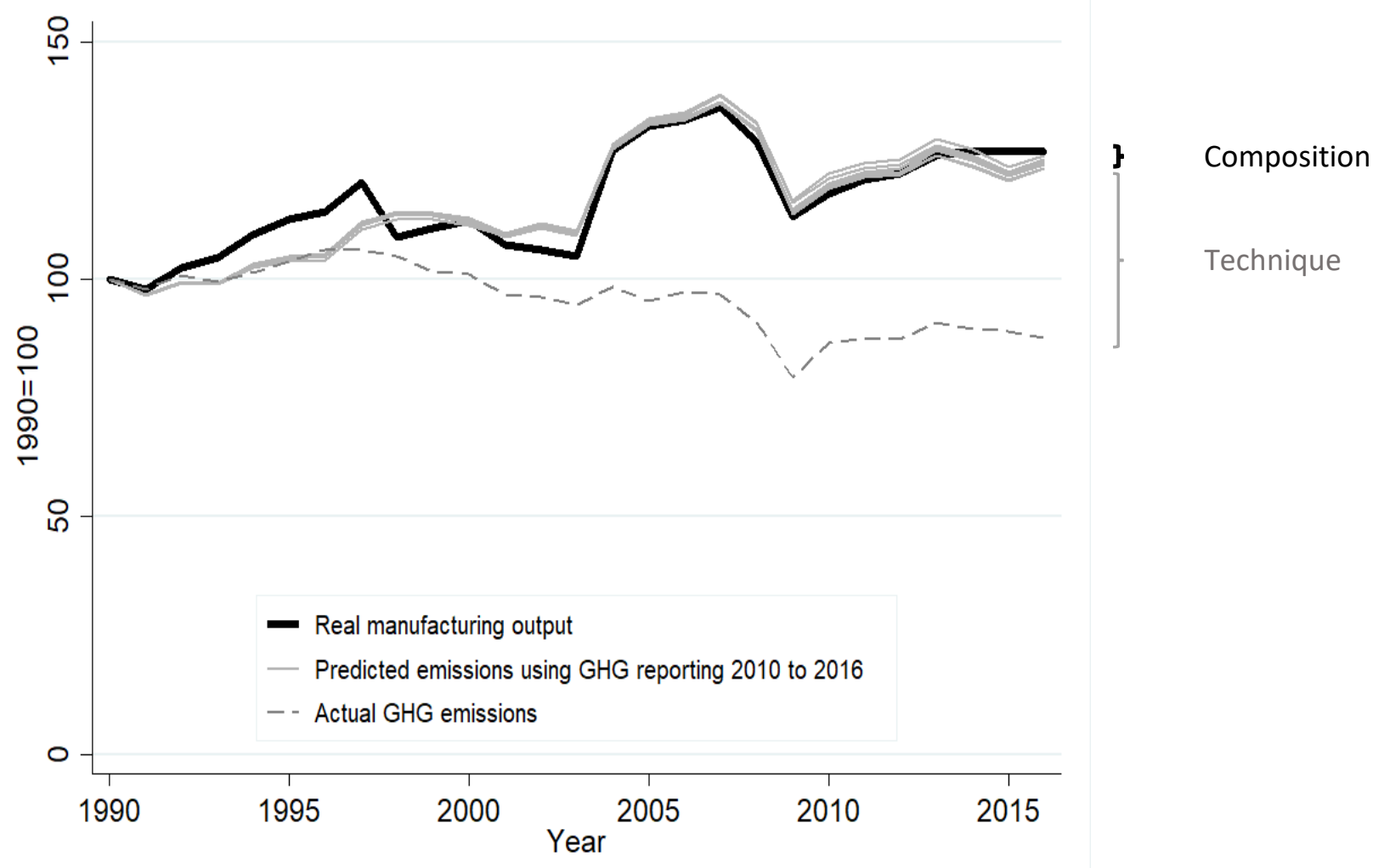


Figure 2. Real manufacturing output and local pollution
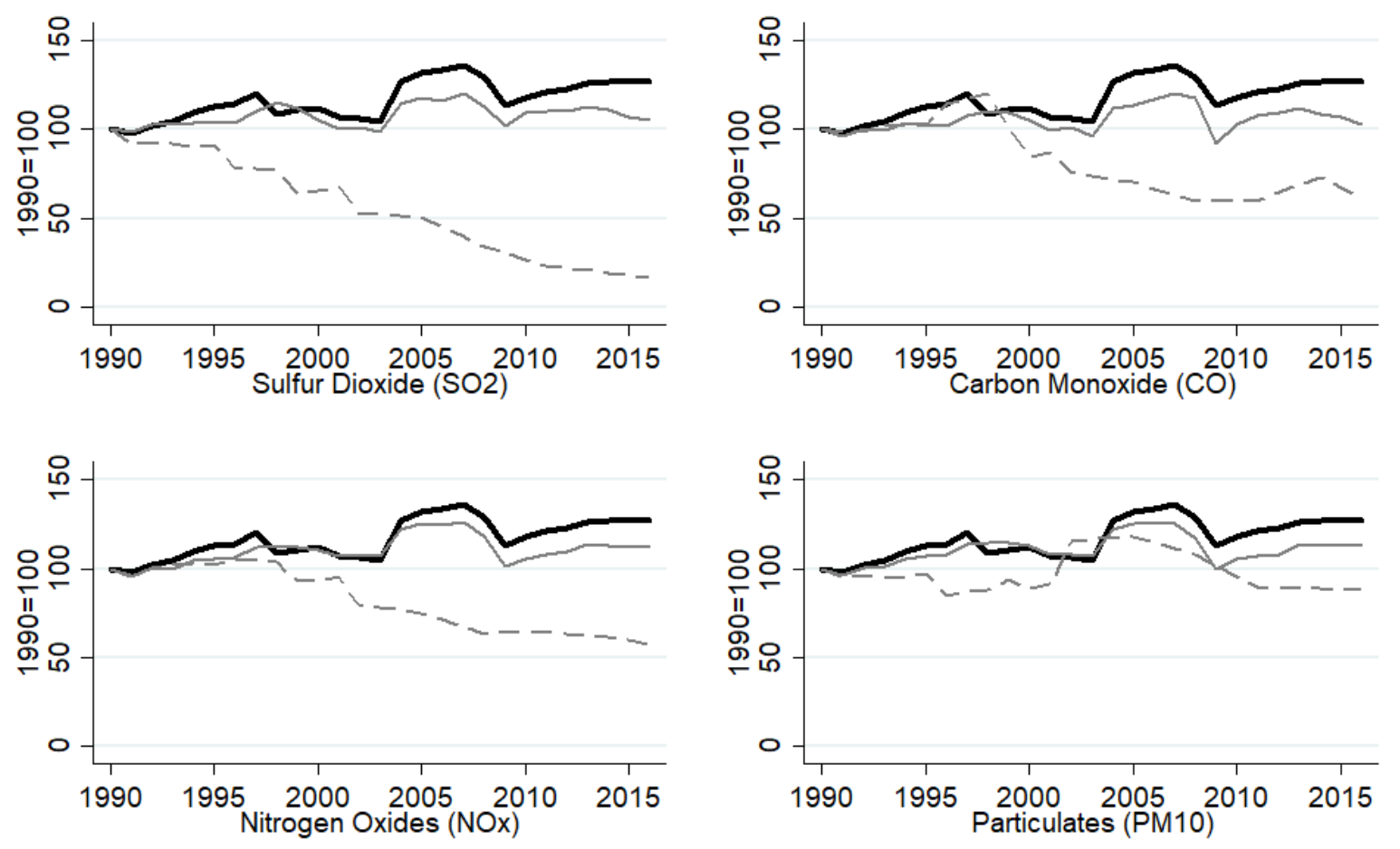

- Real manufacturing output - Predicted emissions - - Actual emissions 
Figure 3. Predicted GHG emissions from US manufacturing, imports and exports

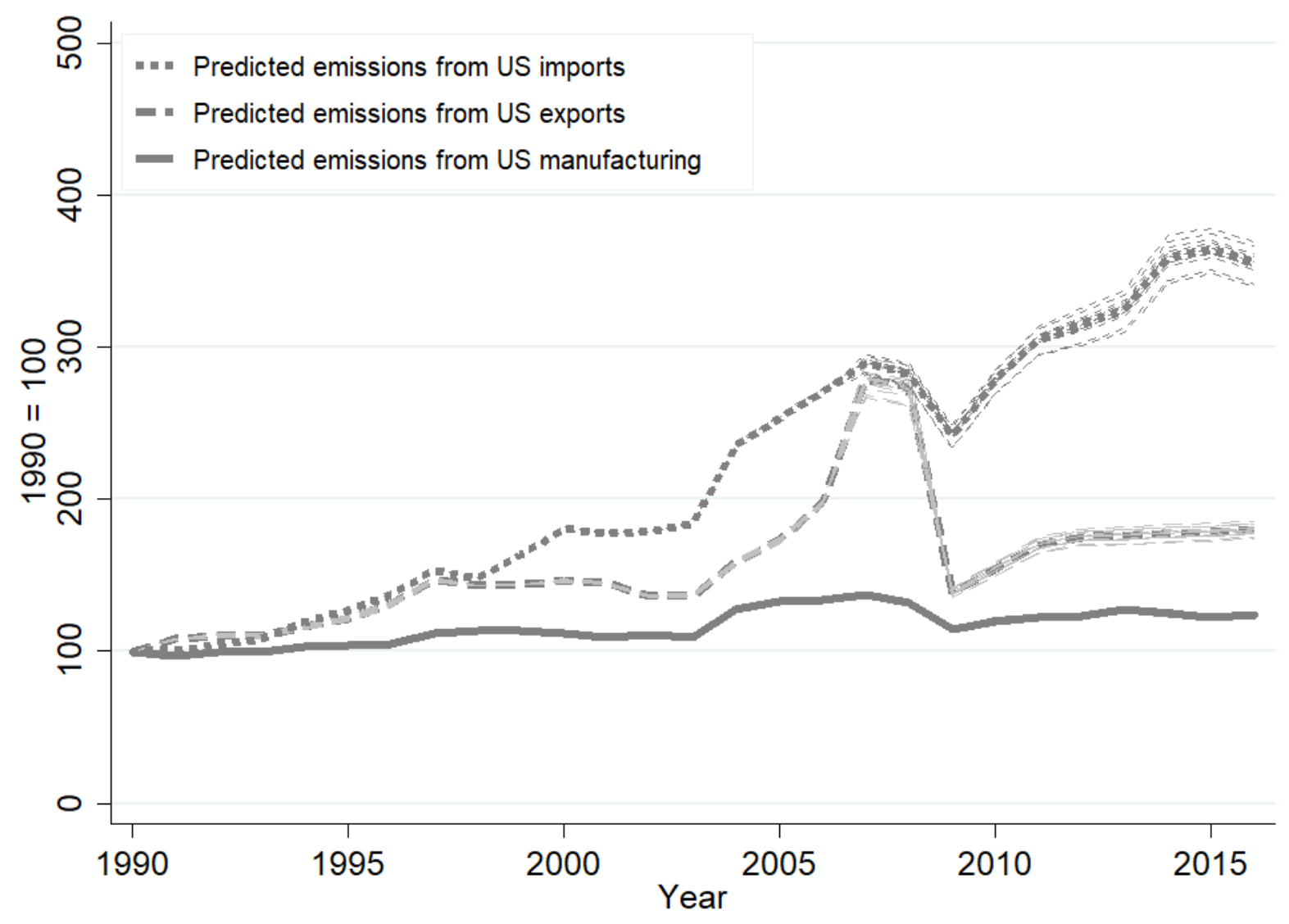


Figure 4. Emissions and value of US exports and imports to (a) all countries (b) high-income countries and (c) low-income countries
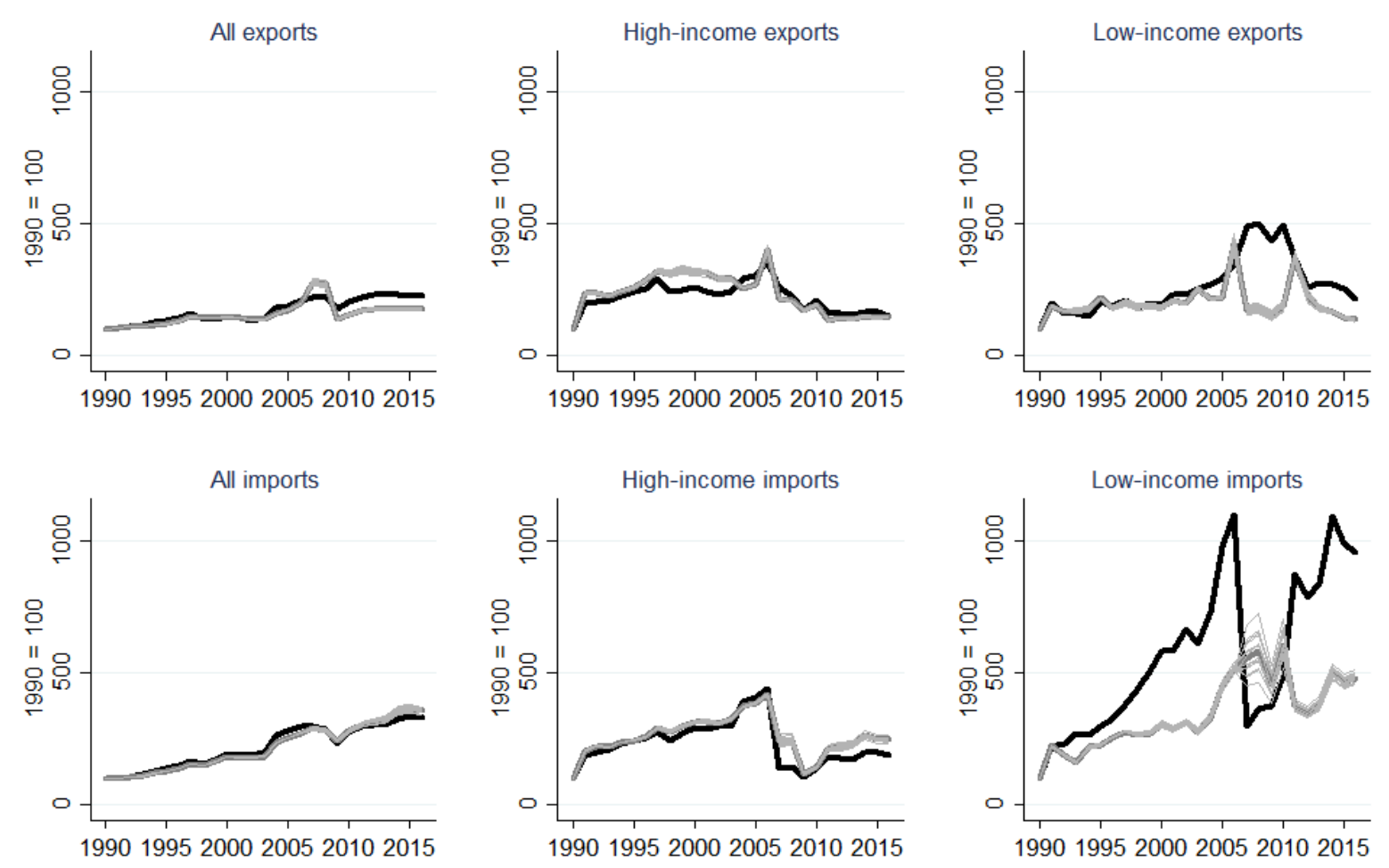

- Real US trade $\quad$ Predicted emissions from US trade 